\title{
Critical Social Study of the Oral Tradition of Coastal Communities in North Bali
}

\author{
I Wayan Mudana ${ }^{1}$, I Putu Putra Yana Wardana ${ }^{2}$ \\ \{wayan.mudana@undiksha.ac.id ${ }^{1}$ \} \\ Universitas Pendidikan Ganesha, Indonesia ${ }^{12}$
}

\begin{abstract}
The Balinese people, when viewed from the livelihood they are engaged in, some of them who pursue marine activities. However, their existence is often squeezed and pushed aside. It can be said that this is a denial not only of the social phenomena of maritime affairs but also of the ideology of nyegara gunung. This phenomenon not only causes economic poverty but also results in socio-cultural poverty. Is in connection with that this study was carried out. The purpose of this study is to critically describe the forms of oral traditions that develop in coastal communities in north Bali. This study is expected to contribute to strengthening maritime literacy in the younger generation. Such efforts are in line with the government's efforts to develop a maritime axis. This study used a qualitative approach, the research informants were determined purposively, data collection was carried out by observation, interviews, and document study, while the data analysis was carried out in a qualitative descriptive manner. Based on the data obtained, it can be argued that the people of north Bali have various forms of oral traditions about nautical. The forms of oral traditions that are owned include ideas about nautical, marine activities, and marine technology.
\end{abstract}

Keywords: critical social studies; literacy, maritime, coastal, North Bali

\section{Introduction}

The Balinese people are experiencing a detachment from traditional culture, namely Balinese language and oral traditions. The erosion of the traditional culture of Balinese society is not only a consequence of the openness of Balinese society in the era of globalization but is also related to the development process with a modernist paradigm that tends to position traditional culture as a barrier to the development process. As expressed by one of the figures who designed the modernist paradigm of Mcclelland in achievement motivation theory, traditional culture is declared to be fatalist [1];[2];[3];[4]. Such views lead to the erosion of various traditional cultures such as local wisdom, local languages, folk stories, and traditional games. This can be seen from the displacement of oral traditions by modern cultures originating from abroad. In this connection, this study was conducted.

Another phenomenon that also inspired this study was the exclusion of coastal communities. This phenomenon not only causes the marginalization of coastal communities but also destroys the culture and the environment consistently. This concern is getting stronger with the change in the work orientation of the young generation outside the marine sector. This condition is exacerbated by the limited discourse of marine culture in the social studies learning process at elementary schools in coastal areas of Bali. This happened as a consequence of the existence of marine and fisheries development being outside the mainstream for three decades 
so that the sea moved away from the imagination of coastal children. This is certainly a "the irony of a maritime state, whereas in a historical perspective it is revealed who controls the oceans, he will rule the world, as expressed by Dahuri (kompas, friday, january 17, 2014). It is in this context that the development of maritime literacy is very important. As one of the steps that need to be taken in protecting and empowering the community and coastal/marine culture as expressed by Arif satria in Kompas Thursday, march 17, 2016. So that maritime literacy, maritime culture has a diversity and meaning in a maritime country.

From various literature studies that have been carried out, it is revealed that there is the strength of marine culture which can be used as a basis in liberating coastal communities from the shackles of underdevelopment, sociocultural poverty, and developing resources and strengthening the competitiveness of the nation [5];[6];[7];[8];[9];[10];[11];[12];[13];[14]. This is in line with the sustainable development paradigm, which emphasizes the importance of the economic, environmental, and socio-cultural sustainability of local communities. Based on the background of the problems mentioned above, this study is focused on critically describing the forms of oral traditions that develop in coastal communities in north bali.

In examining this, theories related to maritime literacy, oral traditions as socio-cultural capital[15], and socio-cultural construction [16] will be used. This study used a qualitative approach, the determination of the informants was done purposively, the data was collected using interviews and literature studies, while the data analysis using a qualitative descriptive.

\section{Methods}

This study used a qualitative research design. Located in the Coastal Communities in North Bali. Methods of collection using observation techniques, interviews, document study. The data analysis techniques used are data reduction, data presentation and conclusion drawing.

\section{Result and Discussion}

Based on the data collected by the population of Bali in 2019, it is estimated that there are 4.36 million people, with 27,297 people as marine fishermen, 3,815 fish processors, 786 fish cultivators. The fishing communities in the coastal areas of Bali generally live in poverty. This can be seen from the limited financial capital it has. The picture of poverty in fishing communities can be seen from the condition of the settlements, their household facilities, the level of education, and mastery of maritime technology.

In terms of the settlement, fishing community housing is generally built on state land in coastal areas. The housing building is very simple and semi-permanent, which uses a wooden/bamboo frame and walls of bedeg or concrete blocks with a tin roof or coconut leaves. Household facilities are generally very limited. Concerning the very simple condition of the housing of the fishing community, the term for the house they own is called the Kubu.

The poverty of the fishing community is also reflected in the low level of education they have. They generally only received a basic education. The limited level of education they have is not only due to low awareness of the importance of education but tends to be due to limited financial capacity. The limited economic capacity of the family causes fishermen's children to be more positioned as part of the production unit to increase family income rather than as a future resource capital. This means that children in fishing families are positioned more as family economic resources than as human resources whose quality must be improved through a formal education process. This condition is also triggered by relatively high funding for formal education. In particular, education funding for higher education, junior high school, high school, and tertiary education 
The limitations of financial capital not only affect the level of education of the people but also have implications for the limited ownership of maritime technology, because each component of maritime technology is obtained through market mechanisms in market institutions, both in traditional and modern markets. Limited mastery of technology has implications for the limitations of fishing communities in utilizing various coastal and marine potentials. The poverty condition of fishing communities of this kind by Chamber illustrates that poverty is experienced in the grip of poverty octopus (1993). This condition encourages them to keep trying to free themselves from the clutches of the poverty octopus. Their efforts to free themselves from the clutches of the poverty octopus are, of course, based on their belief in a certain level of value that is rational in nature and morality in developing a substantial economy or market economy to meet basic needs and improve their quality of life. It is in this context that the fishing community tries to play with various capitals such as natural capital, body capital, financial capital, cultural capital, and social capital. In the process of liberating himself from the poverty octopus, the fishing community in Bali has also developed social and economic credit. These institutions are very meaningful for them in overcoming problems in the life of fishing communities both to the problem of strengthening financial capital, and technology as well as in strengthening human resources. These efforts are very meaningful both in developing service businesses and in developing various diversification of businesses.

In discussing the oral traditions of the coastal communities of North Bali, it seems necessary to borrow the sociocultural concept developed by Koentjaraningrat (1982) which suggests that culture universally has three forms, namely a cultural value system, a social system, and a physical culture. The same thing was stated by Sanderson (1999) who stated that the sociocultural system of society was divided into three, namely: superstructure, ideology, structure, and material infrastructure. Based on this, it can be said that the coastal communities in North Bali have quite an adequate system of maritime cultural values, as expressed by North Balinese community leaders, who state that coastal communities have an idea of maritime which can be seen from the expression nyegara gunung. The Mudana study (2013-2018), reveals that nyegara gunung as the sociocultural capital of Balinese society has a meaning not only as a denotative meaning of sea and mountain but also having a connotative meaning as a living space in scale and abstract. In its existence as a living space that is scalable, nyegara gunung is a space that can serve as an arena for the development of various socioeconomic activities. The awareness of nyegara gunung as living space can be seen from the expression of the Balinese coastal community which states that uma abiane di pasihe.

This awareness is reflected in the existence of various productive activities carried out in coastal areas. In coastal areas, local communities develop productive businesses such as fishing, fish processing, fish marketing, salt production, aquaculture, development of marine technology, and marine tourism activities.

In this area, various facilities and infrastructure have been established to support service activities. This can be seen from the development of fishing settlements, ponds, and ports. Recently, in line with Bali's existence as a tourist destination, it is not uncommon for coastal areas to be developed as tourist areas, especially marine tourism, as happened in North Bali areas such as Pemuteran, Lovina, Les, and Sambirenteng.

The development of marine tourism activities has resulted in changes in land use/land-use change, which has not only resulted in the displacement of fishermen's settlements but has also resulted in the erosion of fishermen in socio-economic activities, which further have an impact on fishermen's life. The construction of tourism facilities and infrastructure like that results in the tightness of the living space of the fishing community. The phenomenon of the development of marine tourism in the coastal area of North Bali has encouraged several members of the 
fishing community to participate in developing their business into the tourism sector, for example as an eye shop trader, masseuse, guide for marine activities, introducing guests to water tourism activities at sea. These efforts are an alternative to overcome the constraints of the economic life of coastal communities. The awareness of the sea as living space can also be heard from the folk song Juru Pencar. The song's lyrics reveal the sea as a promising living space. The lyrics of the song are as follows: "Juru Pencar, Juru Pencar, Mai jani jalan ngejuk ebe, ebe gde gde, ebe gde gde di sowane ajaka liu". The awareness of the sea as a living space increases the intensity of human relations with the sea[2].

Based on this, it is revealed that the sea inspires Balinese people to make the sea not only a living space with an economic dimension but also a socio-cultural dimension. This can be seen from the existence of expressions that have a social control function, such as ngentungan uyah to pasihe, nasikin segara, bedug jukung, lelipi uyahin, gede angin gede ombak. By borrowing concepts from semiotic theory figures, the expression has denotative and connotative meaning[17][18]. Denotative meaning expresses the lexical meaning of throwing salt into the sea. Meanwhile, the connotative meaning of this expression implies conveying something to someone who is more well off both economically and sociocultural, so that the gift has no meaning for the person concerned. This expression has a function as social control in the life of the people of North Bali. The expression is often expressed according to the social context or refers to language ethics following the language sor singgih. This can be seen from the expression with a statement using the subtle Balinese language sekadi nasikin segara.

The expression bedug jukung also has a denotative meaning as one that shows the factual conditions of the jukung/boat and also has a connotative meaning that implies a person's personality that is too rigid and does not easily adjust to social life. The expression gede angin gede ombak also has denotative meaning as the phenomenon of waves from seawater activity which is influenced by the wind, while eating the connotative expresses the behavior of a person who is highly dependent on the strength of the other party. Cultural capital in the form of a cultural value system can also be observed in the beliefs of coastal communities. In the coastal community belief system, there is a belief in the existence of a supernatural ruler of the sea, namely Batara Baruna or Betara Segara. This supernatural ruler of the sea is believed to be the ruler of everything in the sea. In connection with this, every activity carried out by the coastal community always begins with certain rituals. A ritual held by coastal communities as a request for grace and protection during activities at sea. The existence of supernatural powers as rulers in the sea, causes coastal communities to believe that the sea is a space that has religious magical power.

The belief that the sea is a space that has religious magical powers is framed by the conception of the sea as a space of life that is both sekala and niskala. The existence of such a sea is framed in the sociocultural idea of Rwa Binneda in Balinese society. Such belief causes coastal communities to always be careful in treating the sea. This marine phenomenon is what causes coastal communities to position the sea to have religious magical functions, such as a place to pray for water, hugging, cleaning, smelting, and healing. The form of such a sociocultural value system is strengthened by the presence of various rituals held at seas, such as Nyepi Uyah, Nyepi Segara, Melasti, Segara Kertih Rituals, and Piodalan Rituals at Segara Temple.

Another form of socio-cultural capital is the social system. In the context of the social system, the coastal community develops various social groups, such as fishermen groups, fish trader groups, fish processing groups, ornamental fish groups, and pecalang segara. These groups not only have a social integration function but also have a socialization/social construction function and social control. These social groups are always dynamic in the process 
of their functioning. The function of fishermen groups to catch fish, of course, really depends on the technology they master and develop. The technology developed includes boats, nets, scatter, fishing rods, and traps. Thus it can be said that the various forms of socio-cultural capital of coastal communities in Bali not only have denotative meanings but also have connotative meanings. Such oral traditions will have maximum meaning through a critical construction process through various institutions or arenas, both formal and informal (Berger. 1990).

\section{Conclusion}

Based on the above description, it can be said that the coastal communities in north Bali have various forms of oral traditions that can contribute to the development of literacy for maritime culture. The development of maritime literacy certainly goes through a critical construction process using various social theory concepts. So that the detachment of maritime culture and the detachment of coastal communities from marine culture and living space in the era of globalization can be avoided.

\section{References}

[1] T. Campbell, Tujuh Teori Sosial, Sketsa, Penilaian, Perbandingan. Yogyakarta: Kasinus, 1994.

[2] G. Ritzer and B. Smart, Teori Sosial. Bandung: Nusa Media, 2011.

[3] P. Beilharz, Teori-teori Sosial. Yogyakarta: Pustaka Pelajar, 2002.

[4] B. Agger, Teori Sosial Kritis. Yogyakarta: Kreasi Wacana, 2005.

[5] D. Lombard, Nusa Jawa: Silang Budaya. Jakarta: PT Gramedia, 1996.

[6] M. dan D. M. A. Faisal, "KUALITAS AIR PADA SUMBER MATA AIR DI PURA TAMAN DESA SANGGALANGIT SEBAGAI SUMBER AIR MINUM BERBASIS METODE STORET,” J. Jur. Pendidik. Geogr. Undiksha, vol. 7, no. 2, pp. 74-84, 2019.

[7] I. W. Ardika, Laut dan Orientasi Dalam Kebudayaan Bali. Denpasar: Universitas Udayana, 2001.

[8] T. A. Reuter, Budaya dan Masyarakat di Pegunungan Bali. Jakarta: Yayasan Obor Indonesia, 2005.

[9] A. Vickers, Peradaban Pesisir Menuju Sejarah Budaya Asia Tenggara. Denpasar: Udayana Universitas Press, 2009.

[10] A. B. Lapian, Kembara Bahari. Depok: Komunitas Bambu, 2009.

[11] M. Ardison, Sejarah Pelayaran Nusantara Jejak Indonesia di lautan Dunia. Surabaya: Stomata, 2016.

[12] I. W. Mudana, Critical Social Analysis of Maritime Cultural Contruct of Pedagogiy in Bali Coastal Area Elementary School Student. Denpasar: SosHum, 2018.

[13] I. W. Mudana and L. O. A. Basri, "Collaboration of Economic Community, Political Community, and Civil Community in Ivestation Social Capital, For Preservation of Marine and Coastal Envirotment in The Pemuteran Village, Bali,” 2018.

[14] L. O. A. Basri, I. W. Mudana, and A. Rahman, "The Negative Stigma Against the Bajo Tribe and its Impact on Local Culture: Study of the Bajo in Bungin Village of South Konawe.," 2017.

[15] E. Sedyawati, "Sastra dalam Kata, Suara, Gerak, dan Rupa. Dalam Metodologi Kajian Tradisi Lisan, Pudentia MPSS (ed)," 1998.

[16] B. P. L and T. Luckman, Tafsir Sosial atas Kenyataan Risalah Tentang Sosiologi Pengetahuan. Jakarta: LP3ES, 1990. 
[17] U. Eco, Teori Semiotika. Yogyakarta: Kreasi Wacana, 2009.

[18] Y. A. Piliang, Semiotika dan Hipersemiotika. Bandung: Matahari, 2012. 